https://nv.nltu.edu.ua

https://doi.org/10.36930/40310306

Article received 28.04.2021 p.

Article accepted 29.04.2021 p.

UDC 635.[1/.7+9]:727.7

$@ \bowtie$ Correspondence author

N. Ye. Horbenko

nata.horbenko@gmail.com

\title{
ВІДТВОРЕННЯ ЕЛЕМЕНТІВ САДІВНИЦТВА, ГОРОДНИЦТВА ТА РІЛЬНИЦТВА ВІДПО- ВІДНО ДО ІСТОРИКО-ЕТНОГРАФІЧНОГО РАЙОНУВАННЯ ТЕРИТОРІЇ МУЗЕЮ НАРОД- НОЇ АРХІТЕКТУРИ І ПОБУТУ У ЛЬВОВІ ІМЕНІ КЛИМЕНТІЯ ШЕПТИЦЬКОГО
}

Музеї під відкритим небом - одна із найперспективніших форм збереження культурної спадщини народу. До них належить Музей народної архітектури і побуту у Львові імені Климентія Шептицького. Територія Музею поділена на сектори (Бойківщина, Рівнинне Закарпаття, Лемківщина, Гуцульщина, Буковина, Покуття, Західне Поділля, Львівщина та Старе українське містечко, Полісся, Волинь), в яких необхідно зберегти наявні насадження та відтворити автентичну флору згідно 3 відповідними секторами. На підставі літературного аналізу запропоновано доповнити експозиції Музею зонами садівництва, городництва та елементами рільництва відповідних історико-етнографічних секторів. Обгрунтовано значущість комплексного підходу до формування експозиції з включенням відповідної до етнографічного зонування рослинної складової для досягнення композиційної цілісності території, гармонійності сприйняття, достовірності подачі архітектурних об'єктів (експонатів). Розроблено концепцію відтворення культурної флори та озеленення території. Для проєктування та подальшого утримання враховано специфіку об'єктів дерев'яної архітектури, що викладено в універсальних схемах формування насаджень на територіях із різним рельєфом. Проаналізовано особливості розташування елементів на території експозиційних споруд та їх зв'язок із прилеглими насадженнями. Запропоновано широкий асортимент рослин для наповнення етноприродного історичного середовища секторів Музею елементами садівництва, городництва та рільництва. За кожним сектором подано попередню оцінку панівного елемента. Запропоновано сумарну оцінку щодо використання рослин для репрезентації господарювання в історико-етнографічних зонах Музею. Отримані результати роботи свідчать про пріоритетність, складність розміщення та компонування насаджень у окремих зонах. Розроблені рекомендації сприятимуть не тільки збереженню цінних історико-культурних об'єктів Музею, але й слугуватимуть спробою реконструкції ландшафтного середовища, традицій природокористування наших предків, максимально наближених до автентичних.

Ключові слова: скансени; етнографічна зона; культивована флора; музейна експозиція.

\section{Вступ}

Сучасний стан питання. Музей народної архітектури і побуту у Львові імені Климентія Шептицького розташований у Личаківському районі міста в межах регіонального ландшафтного парку "Знесіння" (об'єкт природно-заповідного фонду місцевого значення). Цей об'єкт - музей сільської культури, належить до регіонального типу музеїв, відображає історико-етнографічні райони західних областей України (далі - Музей).

До складу функціональної експозиції Музею входять такі етнографічні сектори: Бойківщина, Рівнинне Закарпаття, Лемківщина, Гуцульщина, Буковина, Покуття. До раніше проєктованої, актуалізованої експозиції належать частково функціонуючі етнографічні сектори: Західне Поділля, Львівщина та Старе українське містечко, а також сектори Полісся та Волинь. Інфраструктурну діяльність музею, в основному, забезпечує зона рільництва та агротехніки, де передбачене влаштування ділянок демонстрації агрокультурних процесів.

Одними із стратегічних напрямів діяльності Музею до 2027 р. є реставрація, збереження та утримання експонатів і об'єктів національної спадщини, які передбачають встановлення зон збереження наявних зелених насаджень, визначення зон регенерації та формування автентичної флори відповідно до історико-етнографічного районування території Музею, будівництво давнього ремісничого містечка 3 відтворенням садівництва, городництва та елементів рільництва в етнографічних зонах. Важливим для Музею також є створення екологічного парку - місця сімейного відпочинку шляхом облаштування експозиційних вольєрів для домаш-

Інформація про авторів:

Горбенко Наталія Євгенівна, канд. с.-г. наук, доцент, кафедра ботаніки, деревинознавства та недеревних ресурсів лісу. Email: nata.horbenko@gmail.com; https://orcid.org/0000-0002-6053-6582

Марискевич Оксана Георгіївна, канд. біол. наук, ст. наук. співробітник, відділ екосистемологіï. Email: maryskevych@ukr.net Курницька Марта Петрівна, канд. с.-г. наук, доцент, кафедра ландшафтної архітектури, садово-паркового господарства та урбоекологіï. Email: kurnytskam@gmail.com; https://orcid.org/0000-0003-1059-9857

Цитування за ДстУ: Горбенко Н. Є. , Марискевич О. Г. , Курницька М. П. Відтворення елементів садівництва, городництва та рільництва відповідно до історико-етнографічного районування території музею народної архітектури і побуту у Львові імені Климентія Шептицького. Науковий вісник НлтУ України. 2021, т. 31, № 3. С. 41-48.

Citation APA: Horbenko, N. Ye., Maryskevych, O. H., \& Kurnytska, M. P. (2021). The restoration of horticultural, gardening and agricultural elements according to the historical and ethnographic zoning of the Lviv Museum of Folk Architecture and Rural Life named after Klymentiy Sheptytskyi. Scientific Bulletin of UNFU, 31(3), 41-48. https://doi.org/10.36930/40310306 
ніх тварин і представників дикої фауни Карпатського регіону, презентації традиційної культури садівництва та городництва для здійснення екоосвітніх заходів. Саме ці напрями визначають актуальність питання, висвітленого у дослідженні [19].

Сформульована постановка завдання дослідження. Завданням дослідження є розроблення концепції збагачення експозиції Музею народної архітектури і побуту у Львові ім. К. Шептицького елементами, що демонструють особливості садівництва, городництва та рільництва відповідно до означених зон. Розроблені рекомендації сприятимуть вдосконаленню експозиції архітектурних споруд-експонатів, матимуть історико-етнографічне, естетичне та пізнавально-виховне значення, підвищать атрактивність цього туристичного об'єкта.

Об'єкт дослідження - територія експозиції Музею, наукові, науково-популярні та інші матеріали щодо садівництва, городництва та рільництва однойменних етнографічних та адміністративних регіонів - експозиційних зон Музею.

Предмет дослідження - елементи садівництва, городництва та рільництва експозиції Музею, які розглядали як з позиції їх реконструкції, вдосконалення, догляду, так і перспективності створення нових.

Мета роботи - розробити концепцію відтворення елементів садівництва, городництва та рільництва відповідно до історико-етнографічного районування на території Музею.

Для досягнення зазначеної мети визначено такі основні завдання дослідження: здійснити вибір елементів (рослинних таксонів), грунтуючись на літературних джерелах із врахуванням особливостей території та експозиції Музею; врахувати особливості розташування елементів на території експозиційних споруд та їх зв'язок із прилеглими насадженнями.

Наукова новизна отриманих результатів дослідження - вперше для території Музею запропоновано концепцію відтворення культивованої рослинності за експозиційними зонами; розроблено конкретні рекомендації та методичні підходи до облаштування ділянок садівництва, городництва, рільництва 3 урахуванням динаміки розвитку рослинних компонентів, їх поєднання 3 наявними об'єктами дерев'яної архітектури, можливості догляду за ними.

Практична значущість результатів дослідження дослідження матиме значення і як науково обгрунтовані рекомендації щодо етнографічної специфіки за зонами, і як інструмент у регулюванні усіх динамічних змін експозиції для демонстрації відтворених елементів садівництва, городництва, рільництва (перенесення об'єктів-експонатів, рубання дерев, прокладання нових маршрутів і стежок та ін.).

Аналіз останніх досліджень та публікацій. Музеї під відкритим небом архітектурно-етнографічного спрямування - це найперспективніший у сучасному суспільстві метод збереження історико-культурної спадщини, який не лише музеєфікує окремі унікальні об'єкти, здебільшого дерев'яної архітектури, але й дає змогу реконструювати, консервувати i транслювати майбутнім поколінням історико-культурне автентичне середовище існування певного етносу [31].

Етнографічні музеї, чи, іншими словами, - музеї під відкритим небом, музеї культури і побуту, скансени - це архітектурно-ландшафтні комплекси, що об'єднують в єдину цілісну систему елементи архітектури, ландшафту, предмети етнографії, культури і господарювання того чи іншого народу або регіону. Вони виступають репрезентантами регіональної етнічної самобутності населення на рівні культурно-побутових особливостей і природокористування, сприяють не тільки збереженню історичної пам'яті і спадку (насліддя), але й стимулюють до самоусвідомлення і самовизначення своєї ментальності.

Незважаючи на досить велику популярність і перспективність розвитку сучасних музеїв під відкритим небом, їх потенціал використовується не повною мірою. Необхідні пошуки нових шляхів підвищення туристичної інтерактивності музейних експозицій.

Серед наукових досліджень 3 питань створення, організації і планування скансенів існує значний блок статей як вітчизняних, так i авторів країн ближнього i дальнього Зарубіжжя - Росії, Грузії, Білорусі, Азербайджану, Латвії, Сербії, Норвегії, Швеції, Нідерландів, Великобританії, Франції. Питання сучасного стану вітчизняних скансенів досліджують такі українські дослідники, як Ю. С. Борисенко (2019), В.В.Вечерський (2011), Л. Ю. Водяник (2012), О.В.Жукова (2011), А. С. Старикова (2018). За цією тематикою є низка публікацій в Україні на рівні спеціальних монографій і дисертаційного дослідження $[5,6,14,24,25]$. Основна увага авторів прикута до історії, класифікації, архітектурно-планувальної організації скансенів, наповненню ї експозицій об'єктами та елементами, аналізу сучасних перспектив розвитку. Водночас, середовищна сутність таких комплексів часто залишається поза увагою.

Ці музейні комплекси доцільно розглядати 3 позиції етнокультурного ландшафту, основними ознаками якого $є$ збереження не тільки традиційних архітектурних і планувальних форм, але відтворення всього природного оточення, ознайомлення 3 традиціями етнічного природокористування певного регіону $[1,18,20]$.

Складною на території етнографічних музеїв вбачається проблема ландшафтного озеленення та належного використання ландшафтних особливостей. Вирішення цього питання потребує допомоги дуже кваліфікованих фахівців: дендрологів, ландшафтних архітекторів, етнографів, географів, дизайнерів та інших [23].

Інноваційність скансенів повинна полягати не тільки у збереженні унікальних історико-культурних об'єктів, але й розміщенні їх у максимально наближеному контексті до того середовища, з якого вони були запозичені.

Ці дослідження і пропозиції є спробою відтворити гармонійне етноприродне історичне середовище на території експозиційних зон музею народної архітектури і побуту у Львові.

Матеріали та методи дослідження. Матеріалами дослідження були літературні джерела, дані маршрутних обстежень та обмірів, аналіз картографічних матеріалів території Музею впродовж 2019 року. Для території здійснено комплексний аналіз об'єктів експозиції, досліджено стан прилеглих до них насаджень. У роботі використано сукупність емпіричних методів: спостереження, порівняння, опис, бібліографічний, історичний та графічний методи. Застосовано стандартні методики досліджень та проєктування об'єктів садово-паркового господарства із врахуванням специфіки об'єкта - етнографічного музею дерев'яної архітектури під відкритим небом. 


\section{Результати дослідження та їх обговорення}

Основні польові дослідження здійснено впродовж 2019 року. Матеріали увійшли у Проєкт [19].

Концепція відтворення культурної флори та озеленення території за історико-етнографічним районуванням, зонуванням - це загальні тенденції формування садів, городів, ріллі зон Музею.

Озеленення території кожної експозиційної зони Музею має враховувати:

1. Відтворення історичного образу культурної рослинності території репрезентованої зони, просвітницькоекологічне доповнення музейної експозиції.

2. Відповідність умов зростання біоекологічним особливостям рослин, перепланування насаджень території 3 урахуванням безпеки та комфорту відвідувачів та працівників.

3. Забезпечення належного та екологічно безпечного догляду за рослинами (науково обгрунтована агротехніка, боротьба із шкідниками та хворобами хімічними препаратами, максимально безпечними для людини, тварин, рідкісної корисної ентомофауни).

4. Створення естетичної композиційної цілісності території Музею.

Під час проєктування елементів садівництва, городництва та рільництва варто враховувати, що об'єкти де- рев'яної архітектури мають свої особливості планування, специфічний оптимальний режим утримання.

Формування насаджень дерев, ягідників, городів, ріллі навколо музейних споруд подано на рис. 1 та 2. Прораховано оптимальні відстані до насаджень, зображено основні тіні від споруд та деревостану залежно від висоти об'єктів та перепаду рельєфу. Розроблено перелік рослин за медопродуктивністю та нектароносністю (для ведення господарства на пасіці, підтримання кормової бази місцевої ентомофауни), що наведено в окремому переліку [19].

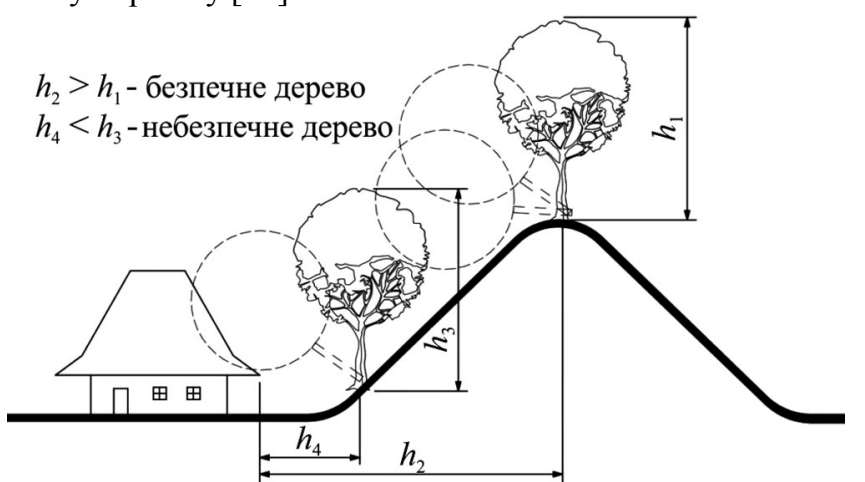

Рис. 1. Формування насаджень на ділянках з перепадом рельєфу

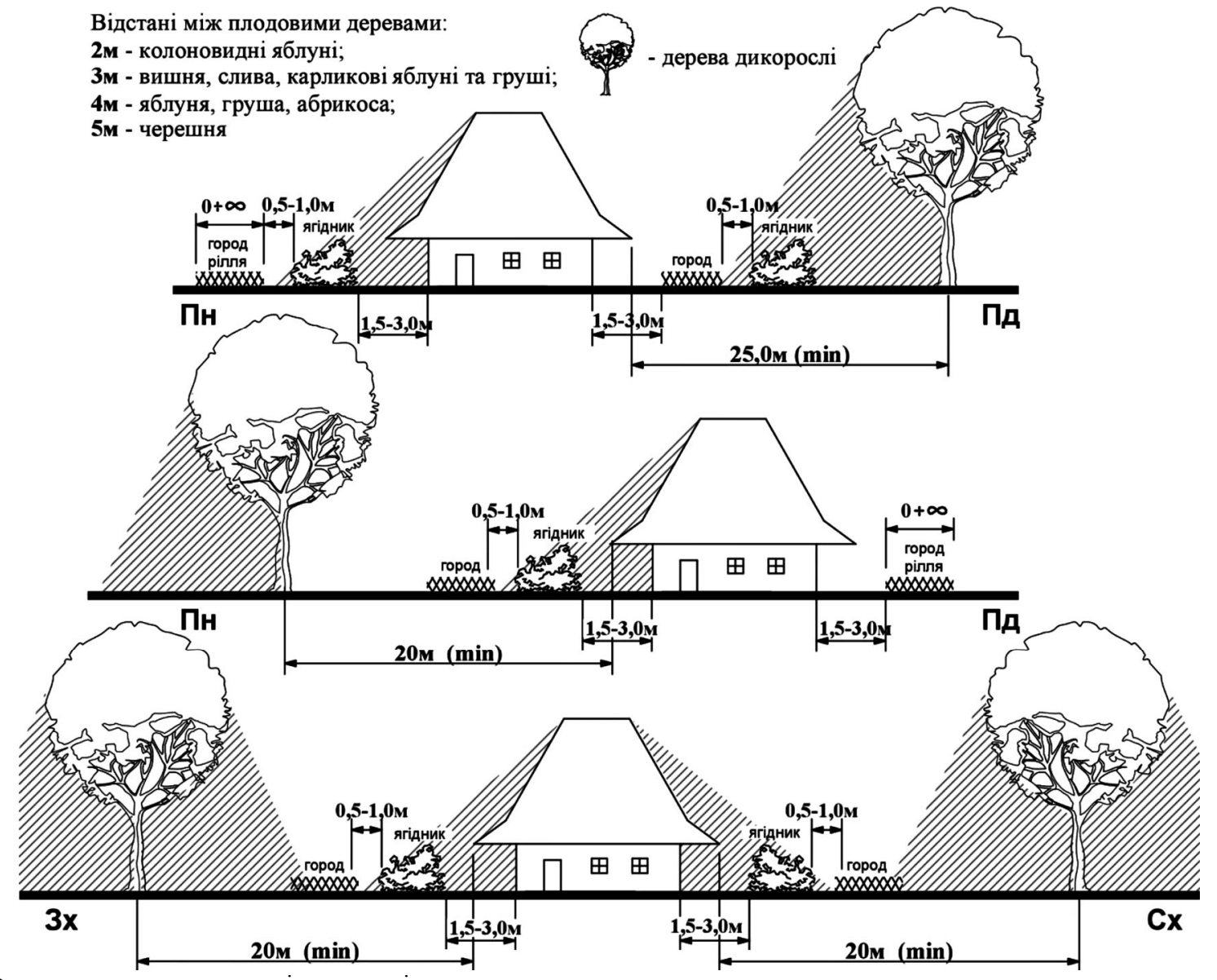

Рис. 2. Формування насаджень на рівнинних ділянках

На рис. 2 наведено схему планування ділянок саду, городу та ріллі на рівнинних ділянках. Розміщення об'єктів подано у трьох варіантах: напрямок північ-південь із розміщенням декоративних дерев на півдні та із деревами на півночі, а також розміщення насаджень за напрямком схід-захід. Ці схеми можна використати для планування будь-якого варіанта розміщення наявних дерев або їх планованих насаджень. Так, можливий ва- ріант дерев із півночі і півдня, і тоді можна скомбінувати перші два варіанти. У разі, якщо планування виконують у напрямку схід-захід, і одна із сторін вільна від деревної рослинності, то можна продовжити ділянку городу та доповнити його ділянкою ріллі.

Проєктування ріллі, городу та ягідника потрібно здійснювати 3 урахуванням руху тіней від високих об'єктів (споруди та дерева, див. рис. 2). Ділянка ріллі 
має бути максимально освітлена, так само як і ділянка городу. Зона ягідника може отримати менше освітлення, оскільки такі кущі, як агрус, порічка, чорна смородина, малина витримують притінення без втрати характерного вигляду та споживчої цінності плодів. На ділянці городу розміщення витких рослин доцільніше 3 північного краю, щоб не затіняти інші рослини.

Пропоновані дерева можуть бути як декоративними, так і плодовими рослинами, рекомендована відстань у разі розміщення 3 півдня до споруд - 25 м, $з$ інших напрямків - 20 м. Плодові рослини саду можуть знаходитися ближче, але потребуватимуть постійного моніторингу. Дотримання таких відстаней забезпечить оптимальний інсоляційний режим для основної споруди та предметів всередині неї, створить відкритий простір навколо споруд, підвищить естетичність та експозиційність території.

Серед наявних декоративних і плодових дерев варто видалити всі пошкоджені, сильно вражені хворобами та шкідниками, старі екземпляри, дерева із поверхневою, так званою "випираючою" 3 грунту кореневою системою, і ті, що спричиняють засмічення території самосівом, створюють захаращеність та загущеність насаджень (дуб північний, клен гостролистий, клен цукристий, клен ясенелистий, алича, робінія, верби, берези, осика, тополі). Ці ж види можуть створювати небезпеку при русі відвідувачів за маршрутом, особливо у місцях із перепадами рельєфу. Дерева поблизу споруд бажано замінити на ділянки плодового саду. Плодові дерева потрібно розміщувати не ближче 5 м до споруд, при цьому підбирати саджанці не на сильнорослих підщепах, ретельно займатися їх формуванням із перших років розвитку підтримуючи низьку чашоподібну крону. Саме такі дерева будуть висотою до 20 м і не створюватимуть небезпеку для споруд та людей. Якщо біля споруд є старі живописні або пошкоджені плодові дерева, то доцільно виконати омолоджувальне обрізування крони із врахуванням умов безпеки, за потреби здійснити лікування та оброблення хімічними препаратами, внесення добрив.

У разі розміщення рослин поблизу будівель варто враховувати дощовий стік із покрівлі. Доцільна при цьому відстань, залежно від архітектурних особливостей споруд, повинна становити 1,5-3,0 м.

Ягідник, город, ріллю варто відокремлювати невеликими стежками завширшки 0,5-1,0 м, які полегшать умови догляду і покращать доступність відвідувачів для знайомства 3 рослинами.

За умови перепадів рельєфу, розміщення об'єктів поблизу периметра Музею, під лініями електропередач, відстані та розміри зон садівництва, рільництва та городництва можуть коригуватися. На схилах крутизною понад 10 градусів (не рівнинні ділянки) варто збільшувати відстань між деревами та кущами, щоб уникнути посилення ерозійних процесів через відсутність трав'яного покриву. За потреби садіння здійснювати мікроплощадками із нахилом у протилежну напрямку схилу сторону. Для окремих ділянок можна організувати терасування, влаштування плетених чи кам'яних підпірних стінок.

На рис. 1 схематично показано можливість пошкодження будівель деревами, що випали зі сторони схилу. На таких ділянках можливі тільки фрагменти городу, ягідники кущів за умови достатнього освітлення та нез- начних ухилів, що спричиняють змив грунту. Оскільки дерева будуть 3 часом рости, то варто ретельно слідкувати, щоб їх висота не перевищила відстані до проєкції виступаючих частин будівлі (покрівлі).

\section{Рекомендації за експозиційними зонами Музею}

Львівщина. У цій зоні найбільше уваги варто приділяти оформленню ділянок саду, городу, а найменше рільництву. А саме у рільництві - культурним злакам, що зумовлене переважанням тут закритих просторів із незначною часткою добре освітлених ділянок.

У садівництві потрібно надати перевагу демонстрації старовинних сортів яблук, груш, агрусу, вишні, порічки, малини та інших плодових (австрійський, польський періоди). За їх відсутності можна підібрати подібні аналоги за описами (смак, господарське призначення, строки дозрівання).

Оформлення зони городництва варто виконувати за участю рослин, що традиційно використовують у галицькій, зокрема львівській, кухні $[8,21,22]$. У цій зоні можлива організація інформаційних стендів щодо приготування традиційних сільських і міських страв Львівщини.

Рекомендована організація городньої ділянки рослинами української та польської кухні: картопля, капуста (сорти, зокрема рання, пізня, цвітна, червона, брюссельська, кольрабі), буряк столовий, хрін (та його декоративна форма), квасоля спаржева, квасоля зелена, горох, боби, морква, петрушка, кріп, кмин, пастернак, любисток, селера, меліса, цибуля (усі види), шпинат, помідор, баклажан, часник, редька, редис, гарбуз, огірки, салат, майоран, кабачки, щавель, кукурудза, пастернак та ін.

На ділянках рільництва можна демонструвати жито, овес, ячмінь, гречку, просо, кормовий та цукровий буряк, льон, гірчицю, брукву.

Гуцульщина. Інформація щодо Гуцульщини $є$ найбільш різнобічною та повною. Тут садівництво та городництво відігравало найменшу роль. Через традиційне переважання тваринництва, можлива організація ділянок кормових, медоносних, ветеринарних рослин, шкідливих та небезпечних для тварин рослин.

Доцільне створення "городця", або так званої "мольфарської" ділянки з лікувальними культурними та дикорослими харчовими ("магічними") рослинами $[11,12]$.

Рекомендований список дикорослих лікарських рослин, пропонованих для вирощування на цій ділянці: перстач прямостоячий (калган), тирлич жовтий (джинджура), сиверсія гірська (підойма), яловець звичайний, шипшина, бузина чорна, верес звичайний, калина звичайна, чебрець, блекота, беладона, арніка гірська, валеріана лікарська, аїр тростиновий, живокіст лікарський, оман високий, підмаренник чіпкий, аконіт, ісландський мох, череда трироздільна, братки, звіробій продірявлений, подорожник великий, хвощ польовий, лопух справжній, м'ята перцева, материнка звичайний, полин звичайний, кропива дводомна, золототисячник малий, цикорій звичайний, ромашка лікарська, підбіл звичайний, деревій звичайний, гірчак перцевий, собача кропива звичайна, конвалія травнева, дивина чорна, алтея лікарська, чистотіл великий, малина звичайна, брусниця звичайна, чорниця, ожина звичайна, суниця звичайна, сосна звичайна, вільха чорна, вільха сіра, дуб звичайний, бук лісовий, береза повисла, ялина (смерека), ясен звичайний, верба, липа широколиста, глід, ліщина звичайна. 
Окремо варто виділити городні та декоративні лікарські рослини, що використовували на Гуцульщині, а саме: горіх грецький, часник, цибуля, картопля, морква, біб, капуста, буряк, петрушка, жито, овес, ячмінь, пшениця, кукурудза, льон, коноплі, кріп, кмин, тютюн, хрін, м'ята кучерява, рута запашна, любисток, календула, шавлія, лілія біла, настурція, полин деревовидний (боже дерево), осика, васильки, верба.

Під час створення спеціальних грунтових умов можливе формування ділянки із журавлиною, брусницею (гогодзи), чорницею [3, 13].

У цій зоні можливі ділянки витких городніх та харчових рослин: хміль, квасоля, боби.

Якщо будуть закладати ділянку традиційного городу, то до асортименту доречно включити: картоплю, боби, буряк столовий, буряк кормовий, квасолю, капусту, цибулю, часник, моркву, огірки, горох, кріп, хрін, мак, теоретично (за умови спеціальних дозволів) - коноплі, хміль, льон (пивоваріння, масла) [9, 16].

Для зони рільництва: овес, ячмінь, жито яре та озиме, у менших обсягах кукурудза, пшениця, просо, гречка. Із технічних культур: льон та коноплі $[13,16]$.

Садову зону можуть формувати: яблуня, груша, слива (чорно- та білоплідні сорти), черешні, агрус, порічки $[13,16]$.

Важливою частиною зони Гуцульщини може стати створення ділянки сінокосу та пасовища, що за звичаєм має бути ретельно відокремлена після дня Св. Юрія (5 травня) [16].

У пішохідній зоні та зоні, прилеглій до музейних об'єктів цієї території, варто виділити плакорну ділянку та очистити від деревно-кущової рослинності. Таке розташування полегшить розміщення зони саду та городу, убезпечить відвідувачів від падіння дерев, а також покращить мікроклімат, зокрема інсоляційний режим біля споруд.

Бойківщина. За господарюванням ця зона незначно відрізнятиметься від Гуцульщини. Тому пропонуємо аналогічний баланс площ культурних рослин.

У цій зоні варто відобразити суворіші умови, що подекуди $є$ критичними. Рекомендовано створення ділянки рослин із підземною їстівною частиною (бульбоносних, кореневищних та ін.): ріпа, редька, морква, буряк, цибуля, часник, картопля, петрушка, пастернак. Також доцільне формування ділянок харчових дикорослих рослин, та рослин, що використовуються для приготування дичини. Це: цибуля ведмежа, цибуля ріпчаста, часник, ялівець звичайний, лілія лісова, примула, лобода, яглиця, кропива, дягель та ін.

Вирощування на ріллі: картопля, овес, просо, жито [3].

Городні рослини: аналогічно зоні Гуцульщини.

Оформлення садиби в зоні Бойківщини потрібно виконувати згідно з даними дослідників [6]. Можна висадити на відстані декілька ясенів, з яких традиційно бойки виготовляли вози, тому садили неподалік житла. Якщо сприяють умови, то можна висадити або залишити під час реконструктивних робіт дерева берези та липи - традиційні бойківські джерела деревини, соку, цвіту.

Зона саду не обов'язкова, але за потреби можна включати до неї яблуні, груші, сливи, порічки; зазвичай іiі треба огородити.

Біля хати обов'язково варто висадити м'яту, любисток, барвінок. На городі бойки вирощували капусту, біб, цибулю, огірки, буряки. Після Першої світової війни з'явилась квасоля. Сіяли також льон, а на бойківському Закарпатті - коноплі.

Лемківщина. Зона Лемківщини має відобразити історичний аспект господарства цього краю $[15,30]$. Зважаючи на кам'янисту землю, для ведення продуктивного хліборобства географічні умови Лемківщини не $є$ сприятливими.

Ділянка ріллі має демонструвати овес, жито, інші зернові (пшениця (полба), ячмінь для південних районів Лемківщини, просо), кукурудзу, гречку, ріпак.

Зона городу може включати: картоплю, бобові (гоpox, біб, квасолю), капусту, часник, цибулю, буряк, кріп, петрушку, моркву, технічні культури (льон, коноплі, менше хміль) тощо.

Сад можуть формувати яблуні, груші, сливи, черешні. Подекуди культивували волоські горіхи, вишні, а 3 кущових рослин - агрус. Сад варто організовувати за звичаєм виключно неподалік будинку.

Бажане відтворення природного ландшафту, тому доцільно ввести на південно орієнтованих узліссях дикорослі терен та ялівець.

Закарпатmя. Рекомендовано створити сад із сортів яблуні, груші, кісточкових - вишні та сливи. За умови розчищення південно орієнтованої захищеної ділянки можливе закладання саду з теплолюбних та екзотичних кісточкових і зерняткових плодових дерев: черешні, абрикоси, персика, айви, а також організація виноградника.

Можлива організація ділянки рослин закарпатської та угорської кухні: перець гіркий (та його форми), кукурудза, цибуля, часник та ін.

Також рекомендовані овочеві культури: солодкий перець, кабачок, баклажан, кольрабі, білоголова та цвітна капуста, картопля, петрушка, зелений горошок, помідор, редиска, салат-латук, ревінь.

Цікавим було б створення ділянки верб для заготівлі лози та організація демонстраційної зони під навісом для плетених скульптур і виробів.

Поділля. На ділянці Поділля необхідна велика зона садівництва, городництва, рільництва. У рільництві основна роль відводиться злаковим рослинам [2].

Рекомендовано створення ділянки 3 навісом, під яким щорічно створювати виставку снопів, виробів із соломи (солом'яна скульптура, дідухи).

Доцільне формування ділянки харчових дикорослих і культивованих рослин. Це можуть бути: меліса, м'ята, катран, кріп, аніс, селера, петрушка, материнка, чебреці.

До городнього асортименту рослин варто включати традиційні види: капусту, цибулю (види), часник, буряк столовий, горох, моркву, ріпу, а також види, що з'явилися дещо пізніше - огірки, гарбузи, картоплю, петрушку, хрін, пастернак, кріп, редьку, біб, квасолю, помідори $[2,10,17]$.

Види, вирощувані на ріллі: пшениця, жито, ячмінь, кукурудза, овес, просо, гречка, соняшник, горох. Одна 3 обов'язкових культур - коноплі (матерні та плокогінні). Також культивувалися льон, тютюн, мак [2, 10, 17].

Сад має включати яблука, груші, вишні, сливи, порічки, смородину, рідше малину та агрус [2, 17]. Найвідоміші сорти подільських плодових: яблука - "книш", груші - "глек", "іллінка". За можливості варто віднайти ці сорти. Із сортів слив доцільно підібрати такі, з яких виготовляли чорнослив, що навіть експортували з Поділля [2].

Також традиційним було бджільництво, тому пасіка буде цінним елементом господарства. 
Вагому роль у господарстві відігравало збиральництво. Тому у деревостанах та на прилеглих територіях можна запроєктувати висаджування барвінку, з якого плели весільні букети, ягідних та плодових лісових рослин (суниць, ожини, малини, чорниць), черемхи, калини, здичавілої вишні, яблуні, груші, терену, бузини, пасльону, шипшини), берези, бука, липи, дуба звичайного, ліщини, лікарських трав (дикий щавель, кмин, лобода, кропива, кульбаба, лісовий часник, цибулька, лопух).

Полісся. Для зони Полісся рекомендовано відтворення характерної лісової рослинності або ії фрагментів. Можна створити ділянки із сосновим (у підліску рододендрон жовтий) та смерековим лісом, за спеціальних умов - заболоченої ділянки (журавлина, брусниця, лохина, багно, аїр).

Бажано ввести в городні посадки брукву як культуру, характерну для північних районів України [21].

Основні зернові культури - озиме жито та овес, ярий ячмінь, гречка. Основна технічна культура - льондовгунець. Можна створити демонстраційну ділянку для хмелю, частково використавши сучасні українські сорти.

Для демонстраційної ділянки городу рекомендовані: картопля, капуста, ріпа, цибуля, морква, буряк, часник, гарбуз, кріп, петрушка, квасоля, горох.

Волинь. Для саду рекомендовано сорти яблук, груш, вишні, сливи, агрус, порічки, чорна смородина, малина. У рільничій зоні - усі злаки, окрім пшениці.

Рекомендовано створення ділянок сортової колекції картоплі та волокнистих, технічних рослин (льон, кропива, технічні коноплі).

Для демонстраційної ділянки городу запропоновано ті самі види, що і для ділянки Полісся.

Буковина. Для ділянки садівництва рекомендовано підбір сортів кісточкових порід: вишні, сливи, аличі, черешень, абрикоси; горіхоплідних: ліщини, горіха грецького; зерняткових: яблуні, груші.

Рекомендована організація ділянки з рослин української, молдавської, румунської кухні: кукурудза, перець гіркий та болгарський, квасоля та ін. [27].

Рекомендовані також основні городні: капуста, квасоля, часник, буряк столовий, морква, корінь петрушки, кольрабі, картопля, ріпчаста цибуля, цвітна капуста, гоpox, гарбуз і помідор. Тут використовують виноград як овочеву рослину для приготування голубців у виноградних листках.

Таблиця. Рекомендації введення господарських зон та інших видів використань рослин в етнографічних зонах території Музею*

\begin{tabular}{|c|c|c|c|c|c|c|c|c|c|c|c|}
\hline \multirow{3}{*}{$\begin{array}{c}\text { Етнографічна } \\
\text { зона }\end{array}$} & \multicolumn{10}{|c|}{ Галузь, характер використання } & \multirow{3}{*}{$\begin{array}{l}\text { Сума } \\
\text { балів }\end{array}$} \\
\hline & \multicolumn{2}{|c|}{ садівництво } & \multicolumn{2}{|c|}{ городництво } & \multicolumn{2}{|c|}{ рільництво } & \multirow[b]{2}{*}{ лікарські } & \multirow{2}{*}{\begin{tabular}{|c|} 
медонос- \\
ні, кор- \\
мові
\end{tabular}} & \multirow{2}{*}{$\begin{array}{l}\text { декора- } \\
\text { тивні }\end{array}$} & \multirow{2}{*}{$\begin{array}{c}\text { дикорос- } \\
\text { лі }\end{array}$} & \\
\hline & плодові & ягідні & овочеві & $\begin{array}{c}\text { зеленні, } \\
\text { пряні }\end{array}$ & зернові & технічні & & & & & \\
\hline Львівщина & 3 & 3 & 3 & 3 & 1 & 1 & 1 & 1 & 1 & 1 & 18 \\
\hline Гуцульщина & 1 & 1 & 1 & 1 & 1 & 1 & 3 & 3 & 1 & 3 & 16 \\
\hline Бойківщина & 1 & 1 & 1 & 1 & 1 & 1 & 2 & 3 & 2 & 3 & 16 \\
\hline Лемківщина & 1 & 1 & 1 & 1 & 1 & 1 & 2 & 3 & 2 & 3 & 16 \\
\hline Закарпаття & 3 & 3 & 3 & 3 & 1 & 1 & 1 & 1 & 1 & 2 & 19 \\
\hline Поділля & 3 & 3 & 3 & 3 & 3 & 3 & 1 & 1 & 1 & 1 & 22 \\
\hline Полісся & 2 & 1 & 2 & 1 & 1 & 3 & 1 & 1 & 2 & 3 & 17 \\
\hline Волинь & 3 & 3 & 2 & 1 & 3 & 3 & 1 & 1 & 1 & 1 & 19 \\
\hline Буковина & 3 & 2 & 3 & 3 & 2 & 1 & 1 & 1 & 1 & 1 & 18 \\
\hline Покуття & 3 & 1 & 3 & 3 & 1 & 3 & 1 & 1 & 1 & 1 & 18 \\
\hline
\end{tabular}

Примітка: *1 - не обов'язкова; 2 - бажана для введення (зайняття вільних площ, обов'язковість 1-3 компонентів); 3 обов'язкова.
Ділянка ріллі: можлива демонстрація усіх злакових.

Покуття. Рекомендовано створення колекції декоративних овочів: огірки, гарбузи, кукурудза.

Можливе створення колекції фарбувальних і одночасно декоративних рослин: дрік фарбувальний, нагідки, чорнобривці, настурція, мальва, алтея лікарська, волошка польова, материнка звичайна, живокіст лікарський, ромашка лікарська, деревій звичайний, череда трироздільна, чистотіл та ін.

На цій же ділянці можна висадити цибулю ріпчасту, обгортками якої здавна фарбували їжу, ополіскували волосся; буряк та моркву (мають фарбувальний сік), зелені культури - петрушку, кріп. Якщо є місце - влаштувати спеціальну ділянку чорниць, що мають фарбувальний сік. Також можна залучати у посадки верби і горіх грецький, що мають фарбувальні властивості.

Для Покуття можливе створення найширшої зони садів, оскільки тут була одна 3 найсильніших традицій цієї галузі. У саді рекомендовані види та сорти яблук, груш, слив, вишень, агрус, малина, порічки. Було також розвинуте бджолярство та шовківництво. Можливе висаджування шовковиці білої (морви), персиків, горіха грецького, створення виноградника [28].

Згідно з даними Я. Тараса (2017), біля садиб на Покутті можливе створення навколо тину ("плоту") декоративних насаджень із таких видів: верби, акації, тополі, осики, ясена, бузини. Дерева ясена висаджували по краях садиб для осушення хати, а робінію псевдоакацію (білу акацію) - як загорожу від пилу. Традиційними для Покуття були огорожі з диких троянд (руж) навколо сіл, а з початку XX ст. їх змінили грабові та букові живоплоти. Багато місць було засаджено сортовими яблунями, шовковицею. На Покутті найбільше квітників було біля хат, де жили дівчата. У святкові дні вони "закосичувались", тобто вплітали у волосся квіти (косиці). Так, у квітниках традиційними були гвоздики, васильки, м'ята, півонії, калина, чорнобривці, жоржина, любисток, канупер, черевички, настурції, левкой, пахучі резеди, романи, братки, аконіт, піретрум дівочий, ласкавець, рута, барвінок [29].

Рекомендаційні дані з облаштування господарських зон, інших видів використання рослин зведено у таблицю за етнографічними зонами музею. Оцінку виражено у вигляді 3-бальної шкали: 1 бал - не обов'язкова, 2 бажана для введення (зайняття вільних площ, обов'язковість 1-3 компонентів); 3 - обов'язкова. 
Отже, дані таблиці відображають наведену вище інформацію за групами культур у межах господарських зон, оцінку необхідності їх введення. Сума балів, у цьому випадку, є відносною величиною, яка вказує на те, що під час подальших проєктних робіт найбільше уваги варто приділити таким зонам (по спадаючій): Поділля, Закарпаття, Волинь, Львівщина, Буковина, Покуття, Полісся, Гуцульщина, Бойківщина, Лемківщина. У загальну оцінку включені інші види використання рослин, що будуть доповнювати загальну репрезентативність господарювання етнографічної зони. За однакової суми балів пріоритетом є рекомендації введення рослин зони садівництва як компонента, що вимагає довших термінів формування.

\section{Висновки}

Розроблено концепцію відтворення елементів садівництва, городництва та рільництва відповідно до історико-етнографічного районування території Музею, яка включає естетичну, історичну, біоекологічну складові, враховує комфорт і безпеку відвідувачів Музею, науковість та обгрунтованість підходу до формування цих елементів, підпорядкована загальному комплексному підходу до формування території.

Для відповідних експозиційних $30 \mathrm{H}$ здійснено обгрунтований підбір рекомендованих рослинних таксонів (види, роди, у формі наукових і народних українських назв), врахована можливість їх культивування на території. Вибір варто здійснювати залежно від особливостей території, можливостей Музею та зміни його експозиції.

Розроблено універсальний підхід до особливостей розташування елементів на території експозиційних споруд та їх зв'язок із деревами прилеглої території. Наведені схеми та опис взаєморозташування елементів можна використовувати при змінах експозиції та особливостей території, реконструкції наявних насаджень, створенні нових експозиційних споруд.

Під час проектування робіт з відтворення етнографічних зон господарювання Музею 3 набором рослинних компонентів найбільше уваги потрібно приділити таким зонам (по спадаючій): Поділля, Закарпаття, Волинь, Львівщина, Буковина, Покуття, Полісся, Гуцульщина, Бойківщина, Лемківщина.

Подяка. Автори статті висловлюють подяку завідувачці відділу етнографії Музею народної архітектури і побуту у Львові імені Климентія Шептицького п. Марті Цимбровській за допомогу у графічній реалізації рисунків.

\section{References}

1. Afanasyev, O. Ye. (2011). Open-air museums of Ukraine as representatives of regional types nature management. Geography and Tourism, 15, 111-120. Retrieved from: http://nbuv.gov.ua/UJRN/gt 20111519

2. Afanasyev, O. Ye., Burlaka, Ye. V., \& Markina, Yu. M. (2009). Skansen of Ukraine as an important tourist resource. Tourism industry: current status and development priorities: Proceedings of the IV International scientific-practical conference. Luhansk: SI "LNU imeni Tarasa Shevchenka", 80-84. [In Ukrainian].

3. Artiukh, A. F., Balushok, V. G., \& Boltarovych, Z. Ye. (1994). Podillya. Historical and local lore research. Kyiv: Dolya, 504 p. [In Ukrainian].

4. Boltarovych, Z. Ye. (1976). Ukraine in the research of Polish ethnographers of the XIX century. Kyiv: Naukova Dumka, 169 p. [In Ukrainian].
5. Borysenko, Yu. S. (2019). Cultural and leisure activities of architectural complexes of the Skansen type in Ukraine at the beginning of the XXI century. Culture and art in the modern world, 20, 30-43. [In Ukrainian].

6. Brych, M. T. (2020). Architectural and spatial organization of open-air museums in Ukraine. PhD thesis. (Arch. Sci.: 18.00.01). Lviv: Lviv Polytechnic National University, 246 p. [In Ukrainian].

7. Danyluk, A. (2006). Ukrainian open-air museums. History of origin, expositions, problems of development. Ternopil: Navchalna Knyha, 104 p. [In Ukrainian].

8. Danyluk, A. H. (2004). Folk architecture of Boykivshchyna. Housing. Lviv: RPF "Ukayinski Tekhnolohiyi", 168 p. [In Ukrainian].

9. Franko, O. (1992). Practical cuisine. Lviv: Kamenyar, 237 p. [In Ukrainian].

10. Havuka, P., \& Maslyanyk, O. (2016). Hutsul cuisine. Lviv: Tysa, 128 p. [In Ukrainian].

11. Hodovanska, O. (2007). Horticulture and home gardening as a manifestation of the traditional culture of Ukrainians in Opillya. Proceedings on Ukrainian ethnology, 6(X), 45-49. Retrieved from: http://mue.etnolog.org.ua/zmist/2007/45.pdf

12. Holovko, S. V. (Ed.), Naulko, V. I., Artiukh, L. F., Gorlenko, V. F., et. al. (1991). Culture and life of the population of Ukraine. Kyiv: Lybid, 232 p. [In Ukrainian].

13. Holovko, S. V. (Ed.), Naulko, V. I., Artiukh, L. F., Gorlenko, V. F., et. al. (1993). Culture and life of the population of Ukraine. Kyiv: Lybid, 284 p. [In Ukrainian].

14. Hoshko, Yu. (Ed.) (1999). Lemkivshchyna. Historical and ethnographic research. Vol. 1. Materal culture. Lviv: The Ethnology Institute of NAS of Ukraine, 360 p. [In Ukrainian].

15. Hoshko, Yu. (Ed.), Arsenich, P. I., Bazak, M. I., Boltarovich, Z. Ye., et. al. (1987). Hutsul region. Historical and ethnographic research. Kyiv: Naukova Dumka, 472 p. [In Ukrainian].

16. Hudchenko, Z. N. (1981). Museums of folk architecture of Ukraine. Kyiv: Budivelnyk, 120 p. [In Ukrainian].

17. Kayndl, R. F. (2000). Hutsuls: their lives, customs and folk tales. Chernivtsi: NPH "Molodyy Bukovynets", 208 p. [In Ukrainian].

18. Korytko, R. F. (2004). Dobryniv is a village of picturesque Opillia. Lviv: Triada Plus, 416 p. [In Ukrainian].

19. Lokotko, Ye. A. (2018). Architectural-planning organization of the open-air museums on the example of the Transcarpathian region of Ukraine. Architecture: Collection of Scientific Works, 11, 95-101. [In Russian].

20. Maryskevych, O. H. (Ed.) (2019). Report on the provision of services for the development of the project of organization of the territory of the Museum of Folk Architecture and Life in Lviv named after Klimenty Sheptytsky (final) under the contract № 904/19 April 9, 2019 with the Museum of Folk Architecture and Life in Lviv named after Klymenty Sheptytsky. Lviv: Institute of Ecology of the Carpathians, 70 p. [In Ukrainian].

21. Mastenitza, Ye. N. (2015). Cultural landscape as an object of heritage: approaches to study and problems of preservation in openair museums. Tomsk State University Journal of Cultural Studies and Art History, 2(18), 42-51. Retrieved from: https:/cyberleninka.ru/article/n/kulturnyy-landshaft-kak-obekt-naslediya-podhodyk-izucheniyu-i-problemy-sohraneniya-...

22. Nechytailo, V. A., Badanina, V. A., \& Hrytsenko, V. V. (2005). Kulturni roslyny Ukrainy: navch. posib. Dlia stud. VNZ. Kyiv: Fitosotsiotsentr, 351 p. [In Ukrainian].

23. Nechytaylo, V. A., Badanina, V. A., \& Hrytsenko, V. V. (2005). Cultivated plants of Ukraine. Kyiv: Fitosotsiotsentr, 351 p. [In Ukrainian].

24. Open-air museums of Ukraine as promising objects of museum tourism and centers for the preservation of ethnic life in the context of globalization (review of the press, the Internet and unpublished documents 2011-2013), 5/6. (2013). Retrieved from http://nplu.org/storage/files/Infocentr/Tematich_ogliadi/2013/muzei prostoneba

25. Pavliuk, S. P. (1986). Folk farming techniques of Ukrainians of the Carpathians of the second half of the XIX - beginning of the XX century. Kyiv: Naukova Dumka, 171 p. [In Ukrainian]. 
26. Shmelov, V. G. (1983). Open-air museums: Essays on the history of origin and development. Kyiv: Naukova Dumka, 120 p. [In Russian].

27. Skrypnyk, H. A., Popov, B. V. (Ed.). (1989). Ethnographic museums of Ukraine: formation and development. Kyiv: Naukova Dumka, 301 p. [In Ukrainian].

28. Starikova, A. S. (2018). Actualization of cultural heritage in openair museums (on the example of the historical-ethnographic and architectural museum of the reserve "Stara Sarepta"). The Young Scientist, 19, 413-418. [In Ukrainian].

29. Sych, Z. D., \& Sych, I. M. (2005). Harmony of vegetable beauty and benefits. Kyiv: Aristey, 2005, 192 p. [In Ukrainian].

30. Taras, Ya. (2017). Traditional gardening and winegrowing at Pokuttia. The Ethnology Notebooks, 1(131), 129-135. Retrieved from: http://nz.ethnology.lviv.ua/archiv/2017-1/12.pdf

31. Taras, Ya. (2019). Traditional environmental knowledge, sanitary and hygiene on Pokuttia. The Ethnology Notebooks, 3(147), 641-659. https://doi.org/10.15407/nz2019.03.641

32. Tarnovych, Yu. (1964). Illustrated history of Lemkivshchyna. Lemkivshchyna Library; Part 1, $2^{\text {nd }}$. New York: Kultura, 287 p. [In Ukrainian].

33. Tikhonov, V. V. (2004). Features of museification of architectural and ethnographic complexes of the Pre-Baikal region. $\mathrm{PhD}$ thesis.
(Cult. Sci.: 24.00.03). Kemerovo, Kemerovo State University of Culture and the Arts., 197 p. [In Russian].

34. Vecherskiy, V. V. (2011). Historical and cultural reserves: plans for the organization of the territory. Severshchyna in the history of Ukraine: Collection of Scientific Works, 4, 6-10. Kyiv: The Center for Monuments Research of the NAS of Ukraine and USPHCM. [In Ukrainian].

35. Vecherskyi, V. V. (2011). Istoryko-kulturni zapovidnyky: plany orhanizatsii terytorii. Sivershchyna v istorii Ukrainy: zb. nauk. prats, 4, 6-10. Kyiv: Tsentr pamiatkoznavstva NANU i UTOPiK. [In Ukrainian].

36. Vodyanyk, L. Yu. (2012). Open-air museums of Ukraine: geography and tourist-recreational significance. Geography and Tourism, 19, 49-155. [In Ukrainian].

37. Zhukova, O. V. (2011). Activities of private museums based on the museification of historical and cultural monuments as one of the prospects for the development of the museum network in modern Ukraine. Seventeenth Sumtsov Readings: Communication Approach in Museum Business in Response to the Needs of Society. Retrieved from http://museum.kh.ua/academic/sumtsov-conference $/ 2011 /$ article.html?n=50

N. Ye. Horbenko1, O. H. Maryskevych ${ }^{2}$, M. P. Kurnytska1

${ }^{1}$ Ukrainian National Forestry University, Lviv, Ukraine

${ }^{2}$ Institute of Ecology of the Carpathians, NAS Ukraine, Lviv, Ukraine

\section{THE RESTORATION OF HORTICULTURAL, GARDENING AND AGRICULTURAL ELEMENTS ACCORDING TO THE HISTORICAL AND ETHNOGRAPHIC ZONING OF THE LVIV MUSEUM OF FOLK ARCHITECTURE AND RURAL LIFE NAMED AFTER KLYMENTIY SHEPTYTSKYI}

The open-air museums are one of the most promising forms of preserving the cultural heritage of the people. These include the Klymentiy Sheptytskyi Museum of Folk Architecture and Rural Life in Lviv. The territory of the Museum is divided into sectors (Boykivshchyna, Plain Transcarpathia, Lemkivshchyna, Hutsulshchyna, Bukovyna, Pokuttya, Western Podillya, Lviv region and Old Ukrainian Town, Polissya, Volyn), where it is necessary to preserve existing plantations and reproduce authentic flora according to the relevant sectors. One of the strategic directions of the Museum's activity until 2027 is the restoration, preservation and maintenance of the exhibits and objects of national heritage, which provide for the establishment of preservation zones of existing greenery, identification of regeneration zones and reproduction of authentic flora in accordance with the historical and ethnographic zoning of the Museum's territory, construction of the ancient craft town with the reproduction of the elements of horticulture, gardening and agriculture in the ethnographic areas. Exhibition of these elements is crucial in further actions to change the vegetation of the Museum, since it is possible to achieve the compositional integrity of the territory only with a comprehensive approach to the formation of the exhibition, harmony of perception, and reliability of the architectural objects (exhibits). The concept of reproduction of cultural flora and landscaping has been developed. The specifics of wooden architectural objects is taken into account for the design and further maintenance, which are set out in the universal schemes of plantation formation on different terrains. Literature in various related fields was analysed. According to conducted analysis the choice of plants for gardening and farming sections of the Museum was suggested. For each sector, a preliminary assessment of the predominant element is provided. A summary assessment of the use of plants for the representation of management in the historical and ethnographic areas of the Museum is suggested. The obtained results indicated the priority and complexity of the development of plantations in some areas. During the design work on the detailed development of vegetation in the Museum, the following ethnographic zones (in descending order of importance) should be given the most attention: Podillya, Transcarpathia, Volyn, Lviv region, Bukovyna, Pokuttya, Polissya, Hutsulshchyna, Boykivshchyna, Lemkivshchyna.

Keywords: open-air museum; ethnographic zone; cultivated flora; museum exposition. 